\title{
In vitro anthelmintic activity of Lippia gracilis Schauer essential oil against egg-hatching of goat gastrointestinal nematodes
}

\section{Atividade anti-helmíntica in vitro do óleo essencial de Lippia gracilis Schauer contra a eclosão de nematódeos gastrintestinais de caprinos}

\author{
Anna Lopes da Costa Souza' (i) (https://orcid.org/0000-0002-1987-9567) \\ Cristina Karine de Oliveira Rebouças ${ }^{1 *}$ (D) (https://orcid.org/0000-0001-7072-1733) \\ Cynthia Cavalcanti de Albuquerque 2 (D) (https://orcid.org/0000-0002-0959-1404) \\ Cristiane de Carvalho Ferreira Lima Moura' (D) (https://orcid.org/0000-0003-0988-3623) \\ Taffarel Melo Torres ${ }^{1}$ (D) (https://orcid.org/0000-0001-8626-520X) \\ João Inácio Lopes Batista1 (1) (https://orcid.org/0000-0002-4984-2298) \\ Francisco Silvestre Brilhante Bezerra' (i) (https://orcid.org/0000-0001-6484-143X) \\ Ana Carla Diógenes Suassuna Bezerra' (D) (https://orcid.org/0000-0002-1039-5187)
}

\begin{abstract}
Since drug-resistant nematodes became a common problem in sheep and goat industries, alternative methods using natural products have emerged as a viable and sustainable anthelmintic treatment option. Here, the in vitro effect of essential oil extracted from Lippia gracilis Schauer was assessed on the hatching process of nematodes recovered from naturally infected goats. Essential oil at concentrations of $0.08 \%(0.008 \mu \mathrm{L} / \mathrm{mL}), 0.12 \%(0.012 \mu \mathrm{L} / \mathrm{mL})$, and $0.16 \%$ $(0.016 \mu \mathrm{L} / \mathrm{mL})$ was able to induce an average inhibition of $74.7,84$ and $93 \%$, respectively. The effective concentration required to inhibit egg hatching in $50 \%$ of eggs (EC50) was $0.03452 \%$. Therefore, essential oil of L. gracilis showed promisor in vitro anthelmintic results against egg-hatching of goat gastrointestinal nematodes.
\end{abstract}

KEYWORDS: bioprospecting; ovicidal activity; small ruminants.

\begin{abstract}
RESUMO: Como os nematoides resistentes a drogas se tornaram um problema comum nas indústrias de ovinos e caprinos, métodos alternativos que utilizam produtos naturais surgiram como uma opção de tratamento anti-helmíntico viável e sustentável. Aqui, o efeito in vitro do óleo essencial extraído de Lippia gracilis Schauer foi avaliado no processo de eclosão de nematoides recuperados de caprinos naturalmente infectadas. O óleo essencial nas concentraçóes de $0,08 \%$ $(0,008 \mu \mathrm{L} / \mathrm{mL}), 0,12 \%(0,012 \mu \mathrm{L} / \mathrm{mL})$, e $0,16 \%(0,016 \mu \mathrm{L} / \mathrm{mL})$ foi capaz de induzir uma inibição média de 74,7, 84 e 93\%, respectivamente. A concentraçáo efetiva necessária para inibir a eclosão de ovos em 50\% dos ovos (CE50) foi de 0,03452\%. Portanto, o óleo essencial de L. gracilis apresentou resultados antihelmínticos in vitro promissores contra a eclosão de nematódeos gastrintestinais de caprinos.
\end{abstract}

PALAVRAS-CHAVE: bioprospecção; atividade ovicida; pequenos ruminantes.

1 Universidade Federal Rural do Semi-Árido - Departamento de Biociências - Mossoró (RN) - Brazil.

2Universidade do Estado do Rio Grande do Norte - Departamento de Ciências Biológicas - Mossoró (RN) - Brazil.

*Corresponding author: cristina.reboucas@hotmail.com

Received on: 6/24/2019. Accepted on: 09/07/2020 
Goat farming is considered an activity of socioeconomic relevance, since it represents one of the main sources of protein for human consumption. Brazil is among the ten countries that have the largest number of goats in the world, with the largest population of this species concentrated in the Northeast region. According to data from the 2017 Census of Agriculture of the Brazilian Institute of Geography and Statistics, Brazilian goat farming reached 8.25 million head, a 16\% increase in herds when compared to the previous census (IBGE, 2017).

For these small ruminants, the pasture is the most abundant option of feeding due to its lower cost of production. However, this food source provides a greater infection of these goats by gastrointestinal helminths, due to the presence of the infective larvae in the pasture (MELO et al., 2015). This occurs because of inadequate sanitary management, which in turn impedes the productive, nutritional and even reproductive management of these animals. Parasitic diseases are still considered the main cause of death of animals in herds (VERÍSSIMO et al., 2012).

Some of the genera of parasites of major clinical importance for small ruminants are Haemonchus spp., Trichostrongylus spp., Oesophagostomun spp. and Strongyloides spp., of which Haemonchus spp. Is one of the most pathogenic (VERÍSSIMO et al., 2012). In an attempt to control widely disseminated parasitic infections, farmers began using anthelminthic drugs indiscriminately, which probably triggered a process of resistance, that is, the effectiveness of these chemical drugs against these parasites decreased (FORTES; MOLENTO, 2013).

Thus, alternative methods for control of gastrointestinal nematodes have been studied, with emphasis on phytotherapy. The essential oil of many medicinal plants has demonstrated some biological properties, such as antimicrobial, antiviral, antimutagenic, anticarcinogenic, antioxidant, immunomodulatory and anti-inflammatory (RIBEIRO et al., 2017).

Lippia gracilis Schauer is known in Brazil as "rosemaryof-Chapada" or "rosemary-board", an herb commonly found in the Northeast region. It is a plant of semiarid climate that is found predominantly in the states of Bahia, Sergipe and Piauí, presenting as a shrub of about $2.5 \mathrm{~cm}$ high, with small leaves and white flowers (GOMES et al., 2011).

It is possible to extract essential oils of this species from stems, leaves, flowers and roots. The most common use of $L$. gracilis is the treatment of respiratory diseases, being used in colds, flu, bronchitis, coughs and asthma. Generally, members of the genus Lippia have similar chemical compositions, being among the most common components: p-cymene, carvacrol, humulene, thymol and 1,8-cineole; these compounds exhibit antimalarial, antiviral and cytostatic pharmacological activities, and may also be used to control insects and ticks (CRUZ et al., 2013; MELO et al., 2013).

The oil of L. gracilis has already been analyzed for its acaricidal (CRUZ et al., 2013), antidermatophytic and antileishmanial activities (MELO et al., 2013), but its possible action on gastrointestinal nematodes is still unknown. In this context, the objective of this work was to evaluate the inhibitory effect of the essential oil extracted from L. gracilis in the process of hatching of goat gastrointestinal parasites.

The study was carried out in the municipality of Mossoró, which occupies an area of $2099 \mathrm{~km}^{2}$ in the state of Rio Grande do Norte, with a mean temperature between 20 and $40{ }^{\circ} \mathrm{C}$, and a mean humidity between 60 and $80 \%$, sometimes being slightly higher or lower than these values (IBGE, 2012).

All experiments were performed in accordance with the recommended procedures of the National Council for the Control of Animal Experimentation. The study was approved by the Ethics Commission on Animal Experimentation of the Universidade Federal Rural do Semi-Árido (number 23091.009318/2016-40). All experiments were performed by the recommended procedures of the Ethics Commission on Animal Experimentation.

Essential oil was extracted from the leaves of $L$. gracilis. A voucher specimen was deposited under the designation 9317 at the Dárdaro de Andrade Lima Herbarium of the Universidade Federal Rural do Semi-Árido (UFERSA), Brazil.

Extraction of essential oil was performed as previously described by RASOOL; MIRMOSTAFA (2003) (apud COSTAJÚNIOR et al., 2016), where the leaves were macerated for $4 \mathrm{~h}$, subsequently added in $500 \mathrm{ml}$ of water, then hydrodistilled for $90 \mathrm{~min}$. The oil was then isolated using a Clevenger apparatus for $2 \mathrm{~h}$. The isolated oil was analyzed by gas chromatography-mass spectrometry for compounds identification.

Collection of feces was performed after at least 90 days from antiparasitic drugs administration to avoid residual effect. In parasitic resistance region (SANTOS et al., 2014), goats naturally infected were collected directly from the rectal ampulla to perform the fecal egg counting, and results were presented as number of eggs per gram of feces, according to the technique described by GORDON; WHITLOCK (1939) modified by CHAGAS et al. (2011). Eggs were recovered to accomplish the egg hatch test in compliance with the procedures of the World Association for the Advancement of Veterinary Parasitology (WAAVP). The recovery of the nematode eggs was performed according to the methodology of HUBERT; KERBOEUF (1992), where the feces pass through a sequence of sieves containing openings of different sizes $0.150,0.100$, 0.036 and $0.020 \mathrm{~mm}$ for egg retention (COLES et al., 1992).

In the first three sieves, the eggs passed through them, which retained the greatest impurities. However, in the last sieve, the eggs were retained and the water passed through the pores, causing concentration of eggs in a much-diminished volume. Thereafter, the resulting liquid was centrifuged for $5 \mathrm{~min}$. Subsequently, the eggs were found in the pellet formed, then the supernatant was discarded and hypersaturated saline solution was added, aiming to allow the eggs to ascend to the supernatant by density and homogenized solution and centrifuged for another $5 \mathrm{~min}$. Then, the supernatant was washed with distilled water so that the saline concentration was decreased 
and a count of the eggs was made, when the calculation of how much solution should be placed in each well was performed (HUBERT; KERBOEUF, 1992; COLES et al., 1992)

Eggs were pooled and then submitted to treatment using concentrations of $0.08 \%(0.008 \mu \mathrm{L} / \mathrm{mL}), 0.12 \%(0.012 \mu \mathrm{L} / \mathrm{mL})$, and $0.16 \%(0.016 \mu \mathrm{L} / \mathrm{mL})$ essential oil diluted in $3 \%$ Tween 80 (CAMURÇA-VASCONCELOS et al., 2008). As negative control, just Tween 80 was used, and thiabendazole $(32 \mu \mathrm{l} / \mathrm{mL})$ (Sigma-Aldrich, St. Louis, MO, EUA) was used as positive control. The plates were placed in incubator of biochemical oxygen demand at $25^{\circ} \mathrm{C}$ for a period of $48 \mathrm{~h}$. At the end, a solution of lugol's iodine was added to each well and read under optical microscopy, where eggs and first-instar larvae were counted. All assays were repeated five times.

The collected data were analyzed through descriptive statistics, where the mean \pm standard deviation and coefficient of variation analyzed by the SigmaPlot program for Windows (SigmaPlot; Systat Software Inc) version 12.0. Differences among groups treated with different oil concentrations were analyzed using ANOVA $(\alpha=0.05)$, followed by Tukey's posttest $(\alpha=0.05)$, before that were verified the normality of data by Shapiro-Wilk test $(\alpha=0.05)$. Effective concentration capable to inhibit $50 \%$ of egg-hatching (EC50) was calculated with the software GraphPad Prism version 5.0 for Windows (GraphPad Software, USA).

The essential oil extracted from $L$. gracilis used in concentrations of $0.08 \%(0.008 \mu \mathrm{L} / \mathrm{mL}), 0.12 \%(0.012 \mu \mathrm{L} / \mathrm{mL})$, and $0.16 \%(0.016 \mu \mathrm{L} / \mathrm{mL})$ was able to induce inhibition of $74.7,84$ e $93 \%$ of egg-hatching on the egg hatch test, respectively, observing an increase in the inhibition rate in relation to the negative control (32\%). An EC50 of $0.03452 \%$ was observed in this research. The genus Lippia also had its anthelmintic effect tested, such as Lippia sidoides, which showed $56.9 \%$ efficacy in sheep infected with nematodes resistant to ivermectin (ALBUQUERQUE et al., 2006). Previous works have demonstrated the biological activity potential of the L. gracilis essential oil, since its antifungal, leishmanicidal and acaricide activity have been proven (MELO et al., 2013; COSTA-JR et al, 2016). The research in question shows another potential activity for this species, the anthelminthic action against gastrointestinal parasites of goats, with $93 \%$ inhibition of hatching eggs at their highest concentration.

MACEDO et al. (2011) demonstrated the anthelmintic properties of the essential oil of Eucalyptus staigeriana on Haemonchus contortus, with an impact on both egg hatching and larval development, reaching rates of 99.3 and $98.7 \%$ in both, respectively. The essential oil of Piper aduncum had also been tested on $H$. contortus (OLIVEIRA et al., 2014), also demonstrating action on egg hatching.

According to the results for the EC50, the essential oil showed a high activity, not only for the high inhibition rates demonstrated, but also for the fact that the EC50 was below the minimum value tested at work, demonstrating that even at low amounts, the oil has a significant effect.

Gas chromatography-mass spectrometry analysis revealed the predominant compounds of $L$. gracilis essential oil, being carvacrol (41.77\%) and thymol (10.13\%) the major ones. These compounds are generally related as the main active ingredients with antiparasitic action (CAMURÇA-VASCONCELOS et al., 2007). Carvacrol can be involved in acetylcholinesterase inhibition (SANTOS et al., 2014), and has an antioxidant action (KARKABOUNAS et al., 2006), whereas thymol is responsible for $\mathrm{Ca}^{2+}-\mathrm{ATP}$ ase inhibition at endoplasmic reticulum (SÁRKÖZI et al., 2007).

In conclusion, $L$. gracilis essential oil was capable to inhibit significantly egg hatching of goat gastrointestinal nematodes, and therefore could find application in anthelmintic therapy in veterinary practice.

ACKNOWLEDGEMENTS: Not applicable.

FUNDING: This work did not receive any specific grant from funding agencies in the public, commercial, or not-for-profit sectors.

CONFLICTS OF INTEREST: All authors declare that they have no conflict of interest.

ETHICAL APPROVAL: The study was approved by the Ethics Commission on Animal Experimentation of the Universidade Federal Rural do Semi-Árido (number 23091.009318/2016-40).

AVAILABILITY OF DATA AND MATERIAL: The datasets generated and/or analyzed during the current study are available in the Repositório da Biblioteca Orlando Teixeira da Universidade Federal Rural do Semi-Árido (https://sigaa. ufersa.edu.br/sigaa/public/biblioteca/buscaPublicaAcervo.jsf).

AUTHORS' CONTRIBUTIONS: Conceptualization: Rebouças, C.K.O.; Albuquerque, C.C.; Bezerra, F.S.B.; Moura, C.C.F.L., Torres, T.M.; Souza, A.L.C.; Bezerra, A.C.D.S.; Batista, J.I.L. Data curation: Souza, A.L.C.; Bezerra, A.C.D.S.; Batista, J.I.L. Formal analysis: Albuquerque, C.C.; Bezerra, F.S.B.; Moura, C.C.F.L., Torres, T.M.; Souza, A.L.C.; Bezerra, A.C.D.S.; Batista, J.I.L. Methodology: Albuquerque, C.C.; Bezerra, F.S.B.; Moura, C.C.F.L., Torres, T.M.; Souza, A.L.C; Bezerra, A.C.D.S.; Batista, J.I.L. Project administration: Souza, A.L.C.; Bezerra, A.C.D.S.; Batista, J.I.L. Resources: Souza, A.L.C.; Bezerra, A.C.D.S.; Batista, J.I.L. Supervision: Souza, A.L.C.; Bezerra, A.C.D.S.; Batista, J.I.L. Validation: Souza, A.L.C.; Bezerra, A.C.D.S.; Batista, J.I.L. Writing - original draft: Souza, A.L.C.; Bezerra, A.C.D.S.; Batista, J.I.L. Writing - review \& editing: Rebouças, C.K.O. 


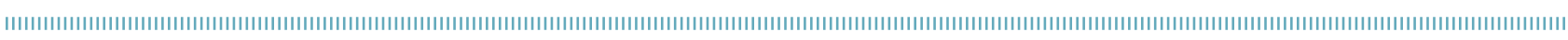
REFERENCES

ALBUQUERQUE, C.C.; CAMARA, T.R.; MARIANO, R.L.R.; WILLADINO, L.; MARCELINO JÚNIOR, C.; ULISSES, C. Antimicrobial action of the essential oil of Lippia gracilis Schauer. Brazilian Archives of Biology and Technology, Curitiba, v.49, n.4, p.527-535, 2006. https://doi.org/10.1590/S1516-89132006000500001

CAMURÇA-VASCONCELOS, A.L.F. et al. Anthelmintic activity of Croton zehntneri and Lippia sidoides essential oils. Veterinary Parasitology, New Zealand, v.148, n.3-4, p.288-94, 2007. https://doi.org/10.1016/j.vetpar.2007.06.012

CAMURÇA-VASCONCELOS, A.L.F. et al. Anthelmintic activity of Lippia sidoides essential oil on sheep gastrointestinal nematodes. Veterinary Parasitology, New Zealand, v.154, n. 1-2, p.167-170. 2008. https://doi.org/10.1016/j.vetpar.2008.02.023

CHAGAS, A.C.S.; NICIURA, S.C.M.; MOLENTO, M.B. Manual Prático: metodologias de diagnóstico da resistência e de detecção de substâncias ativas em parasitas de ruminantes. Brasília: Embrapa Informação Tecnológica, 2011.

COLES, G.C.; BAUER, C.; BORGSTEEDE, F.H.; GEERTS, S.; KLEI, T.R.; TAYLOR, M.A.; WALLER, P.J. World Association for the Advancement of Veterinary Parasitology (W.A.A.V.P.) methods for the detection of anthelmintic resistance in nematodes of veterinary importance. Veterinary Parasitology, New Zealand, v.44, n. 1-2, p.35-44, 1992. https://doi.org/10.1016/0304-4017(92)90141-U

COSTA-JÚNIOR, L.M.; MILLER, R.J.; ALVES, P.B.; BLANK, A.F.; LI, A.Y.; LEÓN, A.A.P. Acaricidal efficacies of Lippia gracilis essential oil and its phytochemicals against organophosphate-resistant and susceptible strains of Rhipicephalus (Boophilus) microplus. Veterinary Parasitology, New Zealand, v.228, p.60-64. 2016. https://doi.org/10.1016/j.vetpar.2016.05.028

CRUZ, E.M.O. et al. Acaricidal activity of Lippia gracilis essential oil and its major constituents on the tick Rhipicephalus (Boophilus) microplus. Veterinary Parasitology, New Zealand, v. 195, n. 1-2, p.198-202, 2013. https://doi.org/10.1016/j.vetpar.2012.12.046

FORTES, F.S.; MOLENTO, M.B. Resistência anti-helmíntica em nematoides gastrintestinais de pequenos ruminantes: avanços e limitações para seu diagnóstico. Pesquisa Veterinária Brasileira, Rio de Janeiro, v.33, n.12, p.1391-1402, 2013. https://doi. org/10.1590/SO100-736X2013001200001

GOMES, S.V.F.; NOGUEIRA, P.C.L.; MORAES, V.R.S. Aspectos químicos e biológicos do gênero Lippia enfatizando Lippia gracilis Schauer. Eclética Química Journal, Araraquara, v.36, n. 1, p.64-77, 2011. https://doi.org/10.1590/SO100-46702011000100005

GORDON, H.M.; WHITLOCK, H.V. A new technique for counting nematode eggs in sheep faeces. Journal of the Council for Scientific and Industrial Research, India, v.12, n. 1, p.50-52, 1939.

HUBERT, J.; KERBOEUF, D. A microlarval development assay for the detection of anthelmintic resistance in sheep nematodes. Veterinary Record, London, v.130, n.20, p.442-446, 1992. https://doi.org/10.1136/vr.130.20.442

Instituto Brasileiro de Geografia e Estatística (IBGE). Produção de Pecuária Municipal. Rio de Janeiro: IBGE, 2012. Available from: https://biblioteca.ibge.gov.br/visualizacao/periodicos/84/ ppm_2012_v40_br.pdf. Access on: 23 Mar. 2018.

Instituto Brasileiro de Geografia e Estatística (IBGE). Produção de caprinos no Brasil. Rio de Janeiro: IBGE, 2017. Available from: http://www.brasil.gov.br/noticias/economia-e-financas/2018/08/ censo-agropecuario-rebanho-caprino-aumentou-16-no-brasil. Access on: 20 Jan. 2018.

KARKABOUNAS, S. et al. Anticarcinogenic and antiplatelet effects of carvacrol. Experimental Oncology, v.28, n.2, p.121-125, 2006.

MACEDO, I.T.F.; BEVILAQUA, C.M.L.; OLIVEIRA, L.M.B.; CAMURÇAVASCONCELOS, A.L.F.; VIEIRA, L.S.; AMÓRA, S.S.A. Evaluation of Eucalyptus citriodora essential oil on goat gastrointestinal nematodes. Revista Brasileira de Parasitologia Veterinária, Jaboticabal, v.20, n.3, p.223-227, 2011 . https://doi. org/10.1590/S1984-29612011000300009

MELO, J.O. et al. Antidermatophytic and antileishmanial activities of essential oils from Lippia gracilis Schauer genotypes. Acta Tropica, Miami, v.128, n. 1, p. 1 10-1 15, 2013. https://doi.org/10.1016/j. actatropica.2013.06.024

MELO, V.F.P.; PINHEIRO, R.S.B.; HOMEM JUNIOR, A.C.; AMÉRICO, J.H.P.; SANTOS, V.C.; ROSESTOLATO, L.L.R. Manejo de antihelmínticos no controle de infecções gastrintestinais em cabras. Revista Brasileira de Saúde e Produção Animal, Salvador, v.16, n.4, p.916-924, 2015. https://doi.org/10.1590/ S1519-99402015000400015

OLIVEIRA, G.L.; VIEIRA, T.M.; NUNES, V.F.; RUAS, M.O.; DUARTE, E.R.; MOREIRA, D.L.; KAPLAN, M.A.C.; MARTINS, E.R. Chemical composition and efficacy in the egg-hatching inhibition of essential oil of Piper aduncum against Haemonchus contortus from sheep. Revista Brasileira de Farmacognosia, Curitiba, v.24, n.3, p.288-292, 2014. https://doi.org/10.1016/j.bjp.2014.07.004

RASOOLI, I.; MIRMOSTAFA, S.A. Bacterial susceptibility to and chemical composition of essential oils from Thymus kotschyanus and Thymus persicus. Journal of Agricultural and Food Chemistry, Munich, v.51, n.8, p.2200-2205, 2003. https://doi.org/10.1021/jfO261755

RIBEIRO, W.LC.; ANDRE, W.P.P.; CAVALCANTE, G.S.; ARAÚJO-FILHO, J.V.; SANTOS, J.M.L; MACEDO, I.T.F; MELO, J.V.; MORAIS, S.M.; BEVILAQUA, C.M.L. Effects of Spigelia anthelmia decoction on sheep gastrointestinal nematodes. Small Ruminant Research, Bet Dagan, v. 153, p. 146-152, 2017. https://doi.org/10.1016/j.smallrumres.2017.06.001

SANTOS, J.M.L.; MONTEIRO, J.P.; RIBEIRO, W.L.C.; MACEDO, I.T.F.; CAMURÇA-VASCONCELOS, A.L.F.; VIEIRA, L.S.; BEVILAQUA, C.M.L. Identification and quantification of benzimidazole resistance polymorphisms in Haemonchus contortus isolated in Northeastern Brazil. Veterinary Parasitology, New Zealand, v.199, n.3-4, p.160164, 2014. https://doi.org/10.1016/j.vetpar.2013.11.006

SÁRKÖZI, S.J.; ALMÁSSY, J.; LUKÁCS, B.; DOBROSI, N.; NAGY, G.; JÓNA, I. Effect of natural phenol derivatives on skeletal type sarcoplasmic reticulum $\mathrm{Ca}^{2+}$-ATPase and ryanodine receptor. Journal of Muscle Research and Cell Motility, London, v.28, n.2-3, p.167-174, 2007.https://doi.org/10.1007/s10974-007-9113-x

VERÍSSIMO, C.J. et al. Multidrug and multispecies resistance in sheep flocks from São Paulo state, Brazil. Veterinary Parasitology, New Zealand, v.187, n.1-2, p.209-216, 2012. https://doi. org/10.1016/j.vetpar.2012.01.013 